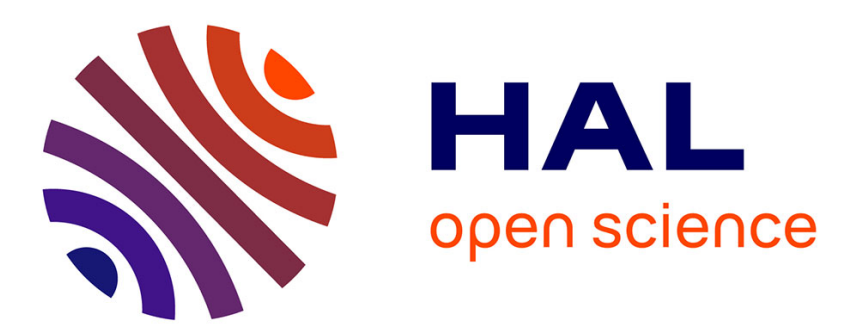

\title{
Metal and metalloid concentrations in the giant squid Architeuthis dux from Iberian waters
}

Paco Bustamante, Angel Gonzalez, Francisco Rocha, Pierre Miramand, Angel

Guerra

\section{- To cite this version:}

Paco Bustamante, Angel Gonzalez, Francisco Rocha, Pierre Miramand, Angel Guerra. Metal and metalloid concentrations in the giant squid Architeuthis dux from Iberian waters. Marine Environmental Research, 2008, 66 (2), pp.278-287. 10.1016/j.marenvres.2008.04.003 . hal-00289572

\section{HAL Id: hal-00289572 https://hal.science/hal-00289572}

Submitted on 22 Jun 2008

HAL is a multi-disciplinary open access archive for the deposit and dissemination of scientific research documents, whether they are published or not. The documents may come from teaching and research institutions in France or abroad, or from public or private research centers.
L'archive ouverte pluridisciplinaire HAL, est destinée au dépôt et à la diffusion de documents scientifiques de niveau recherche, publiés ou non, émanant des établissements d'enseignement et de recherche français ou étrangers, des laboratoires publics ou privés. 
1 Metal and metalloid concentrations in the giant squid Architeuthis dux from

\section{Iberian waters}

3

4 Bustamante $\mathbf{P}^{1^{*}}$, González $\mathbf{A F}^{2}$, Rocha $\mathbf{F}^{3}$, Miramand $\mathbf{P}^{1}$, Guerra $\mathbf{A}^{2}$

5

6 1. Littoral, Environnement et Sociétés (LIENSs), UMR 6250, CNRS-Université de La 7 Rochelle, 2 rue Olympe de Gouges, F-17042 La Rochelle cedex 01, France

9 2. Instituto de Investigaciones Marinas (CSIC), ECOBIOMAR, Eduardo Cabello 6, 36208 10 Vigo, Spain

11

12 3. Departamento de Ecología y Biología Animal, Facultad de Ciencias, Campus As Lagoas13 Marcosende, Universidad de Vigo, 36310 Vigo, Spain

\footnotetext{
*Corresponding author; Phone : +33 546507625 ; Fax : +33 546458 264; E-mail : pbustama@univ-lr.fr
} 
Abstract: This study investigated 14 trace elements (Ag, As, Cd, Co, Cr, Cu, Fe, Hg, Mn, Ni, $\mathrm{Pb}, \mathrm{Se}, \mathrm{V}$ and $\mathrm{Zn}$ ) in the tissues of the giant squid Architeuthis dux from the Mediterranean and Atlantic Spanish waters. As for other families of cephalopods, the digestive gland and the branchial hearts of Architeuthis showed the highest concentrations of $\mathrm{Ag}, \mathrm{Cd}, \mathrm{Co}, \mathrm{Cu}, \mathrm{Fe}$, $\mathrm{Ni}, \mathrm{Se}, \mathrm{V}$ and $\mathrm{Zn}$, highlighting their major role in the bioaccumulation and detoxification processes. With the exception of $\mathrm{Hg}$, the muscles showed relatively low trace element concentrations. Nevertheless, this tissue contained the main proportion of the total $\mathrm{As}, \mathrm{Cr}, \mathrm{Hg}$, $\mathrm{Mn}, \mathrm{Ni}$, and $\mathrm{Zn}$ body burden because muscles represent the main proportion of the squid mass. These findings suggest that the metal metabolism is overall the same as other cephalopod families from neritic waters. In females, $\mathrm{Zn}$ concentrations increased in the digestive gland with the squid's weight likely reflecting physiological changes during sexual maturation. Comparing the trace element concentrations in the tissues of Architeuthis, higher $\mathrm{Ag}, \mathrm{Cu}, \mathrm{Hg}$ and $\mathrm{Zn}$ concentrations in the squid from the Mediterranean reflected different exposure conditions. In comparison to other meso-pelagic squids from the Bay of Biscay, $\mathrm{Cd}$ concentrations recorded in the digestive gland suggest that Architeuthis might feed on more contaminated prey or that it displays a longer life span that other cephalopods.

Key words: trace element; bioaccumulation; cephalopod; giant squid, Architeuthis 


\section{Introduction}

Cephalopods play a key role in marine ecosystems both as predators and prey. They constitute a class of marine molluscs which are found in a great variety of habitats from coastal waters to very deep-ocean environments (Boyle and Rodhouse, 2005). Independently of the species, the habitat or the life span they display, cephalopods share the ability to accumulate inorganic and organic pollutants such as metals, PCBs or organochlorine pesticides (e.g. Martin and Flegal, 1975; Tanabe et al., 1984; Miramand and Bentley, 1992; Yamada et al., 1997; Bustamante et al., 2000, 2006a; Ueno et al., 2003; Storelli et al., 2006). Consequently, they were reported to constitute a significant vector of contaminants to the species feeding on them, in particular seabirds and marine mammals (e.g. Honda et al., 1983; Muirhead and Furness 1988; Bustamante et al., 1998; Lahaye et al., 2005). However, most studies focused on commercially targeted species which are 1) easy to sample and 2) of high economic and health interest concerning human consumption. Many of these cephalopod species are also consumed by top marine predators, but there is a gap in the information concerning non-targeted species. This lack of data on bioaccumulation of contaminants is particularly obvious for oceanic and deep-sea species, like the giant squid Architeuthis.

Overall, the biology, behaviour and life cycle of Architeuthis are still poorly known in many aspects even if this squid has received considerable attention over the last decade (see González et al., 2002; Guerra et al., 2004, 2006; Kubodera and Mori 2005). Most of the information available on this squid comes from dead stranded animals and from predator trophic ecology studies. Indeed, squid flesh and beaks are often recorded in the stomach of sperm whales, but also of seabirds and sharks (Roper and Boss 1982; Clarke 1996; Santos et al., 2002; Cherel and Hobson 2005). Giant squids are also increasingly captured by trawling 
nets because of the development of deep-sea fisheries (Guerra et al., 2006). In deep water conditions, the giant squid would have a particular diet and exposure conditions to trace elements and metals. For example, $\mathrm{Hg}$ bioavailability seems to be enhanced in these deep environments because the absence of solar radiation and the low oxygen concentrations in the deep environment favors a high methylation rate by bacteria (Monteiro et al., 1996). Also, $\mathrm{Cd}$ is enriched in mesopelagic waters while depleted in the surface ocean because of its regeneration from sinking biological debris from epipelagic zone and its uptake by organisms at the surface (Boyle et al., 1976).

In this framework, the objectives of this study were to provide baseline data on a wide range of trace elements in the giant squid Architeuthis dux from the Spanish waters. To this end, the concentrations and tissue distribution of 12 metals $(\mathrm{Ag}, \mathrm{Cd}, \mathrm{Co}, \mathrm{Cr}, \mathrm{Cu}, \mathrm{Fe}, \mathrm{Hg}, \mathrm{Mn}, \mathrm{Ni}, \mathrm{Pb}$, $\mathrm{V}$ and $\mathrm{Zn}$ ) and 2 metalloids (As and Se) were determined in the tissues and organs of fished and stranded specimens. The recorded values were then compared to the data from the current literature for other cephalopod species.

\section{Material and methods}

\subsection{Sampling and sample preparation}

Six specimens of giant squid were collected between 2001 and 2005. Table 1 shows the main data of the specimens as well as the sampling site, date, and mode of capture. Five specimens were caught in the Bay of Biscay (Asturias, North Spain) and one in the western Mediterranean Sea. Two of them were mature males and four were immature or maturing females. 
Collected specimens were immediately frozen prior to dissection. In the laboratory, each individual was weighed and measured (mantle length ML, total length TL), and the sex and maturity stage determined. The digestive gland, gills, ink sack, branchial hearts and their appendages, systemic heart and brain were totally removed. In addition, pieces of muscle, skin, digestive and genital tissues (i.e. oviduct gland, ovary and testis), were sampled to determine trace element concentrations. As it was not possible to separate the different tissues and to weigh them, the total concentrations in the whole Architeuthis specimens were estimated according to the measured concentrations in the different tissues and to their relative weight in fishery targeted squids.

\subsection{Analytical procedure}

All samples were freeze-dried for several days then grounded. Aliquots of the samples ranging from 50 to $300 \mathrm{mg}$ were digested using a 3:1 v:v nitric-hydrochloric acid mixture with $65 \% \mathrm{HNO}_{3}$ (Merck, suprapur quality) and 70\% $\mathrm{HCl}$ (Merck, suprapur quality). Acidic digestion was performed overnight under ambient temperature and then heated in a microwave during $30 \mathrm{~min}$ with increasing temperature until $105^{\circ} \mathrm{C}$, and $15 \mathrm{~min}$ at $105^{\circ} \mathrm{C}$ $(1200 \mathrm{~W})$. After the mineralization process, each sample was diluted to 30 or $50 \mathrm{ml}$ with milli-Q quality water, according to the volume of acid added to the mineralization $(3.0 \mathrm{ml}$ or $4.5 \mathrm{ml})$.

$\mathrm{Ag}, \mathrm{As}, \mathrm{Cd}, \mathrm{Co}, \mathrm{Cr}, \mathrm{Cu}, \mathrm{Fe}, \mathrm{Mn}, \mathrm{Ni} \mathrm{Pb}, \mathrm{Se}, \mathrm{V}$ and $\mathrm{Zn}$ were analysed either by Inductively Coupled Plasma-Optical Emission Spectrometry (Varian ${ }^{\circledR}$ Vista-Pro) or Inductively Coupled Plasma-Mass Spectrometry (Varian ${ }^{\circledR}$ Ultra Mass 700). For $\mathrm{Hg}$, two aliquots ranging from 10 to $50 \mathrm{mg}$ of dried material were directly analysed in an Advanced Mercury Analyser spectrophotometer (Altec ${ }^{\circledR}$ AMA 254). 
106 Reference tissues (dogfish liver DOLT-3, NRCC, and lobster hepatopancreas TORT-2,

107 NRCC) were treated and analysed in the same way as the samples. Results were in good 108 agreement with the certified values, and the standard deviations were low, proving good 109 repeatability of the method (Table 2). The results for standard reference materials displayed 110 recoveries of the elements ranging from $88 \%$ to $116 \%(n=10)$.

111 The detection limits $\left(\mu \mathrm{g} \cdot \mathrm{g}^{-1}\right.$ dry wt) for ICP-OES were 8.3 (As, Fe, Zn), 3.3 (Ag, Se), 1.67 $112(\mathrm{~Pb}, \mathrm{~V}), 0.83(\mathrm{Cd}, \mathrm{Co}, \mathrm{Cr}, \mathrm{Cu}, \mathrm{Mn}, \mathrm{Ni})$, and were $0.167(\mathrm{Ni}, \mathrm{V}), 0.083(\mathrm{Cd}, \mathrm{Co}, \mathrm{Cr}, \mathrm{Cu}, \mathrm{Mn}$, $113 \mathrm{~Pb}), 0.033(\mathrm{Ag})$ for ICP-MS. Trace element concentrations are given relative to the dry 114 weight $\left(\mu \mathrm{g} \cdot \mathrm{g}^{-1} \mathrm{dry} \mathrm{wt}\right)$ while the distribution percentages are calculated for wet weight.

116 3. Results

\subsection{Trace element concentrations in soft tissues}

119 Trace element concentrations in the tissues and organs of Architeuthis are reported in Figure

120 1. Among the sampled tissues, the digestive gland was the major site of concentration for $\mathrm{Ag}$,

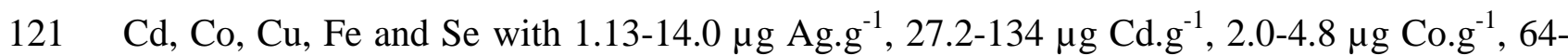
$1221218 \mu \mathrm{g} \mathrm{Cu}^{-1}, 52-1862 \mu \mathrm{g} \mathrm{Fe} . \mathrm{g}^{-1}$ and 9.7-19.5 $\mu \mathrm{g} \mathrm{Se} . \mathrm{g}^{-1}$ (Figure 1). The digestive gland also concentrated $\mathrm{Ni}, \mathrm{V}$ and $\mathrm{Zn}$ at concentrations closed to the highest concentrations recorded in

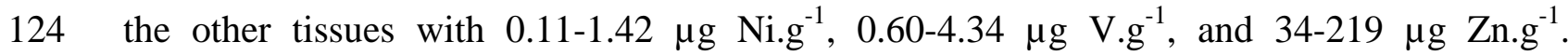
125 Interestingly, the digestive gland also exhibited the lowest concentrations of $\mathrm{As}, \mathrm{Cr}$ and $\mathrm{Hg}$ 126 with 31-65 $\mu \mathrm{g} \mathrm{As.g}{ }^{-1}, 0.41-1.40 \mu \mathrm{g} \mathrm{Cr} . \mathrm{g}^{-1}$, and 0.32-1.56 $\mu \mathrm{g} \mathrm{Hg.g} \mathrm{g}^{-1}$ (Figure 1).

127 The concentrations of $\mathrm{As}, \mathrm{Co}, \mathrm{Hg}, \mathrm{Ni}, \mathrm{Se}$ and $\mathrm{V}$ were also remarkable in branchial hearts, 128 which play an important excretory role in cephalopods. In this tissue, the concentrations of 129 trace elements were the highest for $\mathrm{Ni}$ or very close to the highest for As, $\mathrm{Co}, \mathrm{Hg}, \mathrm{Se}$ and $\mathrm{V}$.

130 Branchial hearts concentrated As from 86 to $111 \mu \mathrm{g} \cdot \mathrm{g}^{-1}$, Co from 3.15 to $3.22 \mu \mathrm{g} \cdot \mathrm{g}^{-1}$, $\mathrm{Hg}$ 
131 from 0.71 to $4.37 \mu \mathrm{g} \cdot \mathrm{g}^{-1}$, Ni from 0.74 to $2.60 \mu \mathrm{g} \cdot \mathrm{g}^{-1}$, Se from 8.2 to $9.3 \mu \mathrm{g} . \mathrm{g}^{-1}$ and $\mathrm{V}$ from

$132 \quad 1.50$ to $2.46 \mu \mathrm{g} \cdot \mathrm{g}^{-1}$ (Figure 1 ).

133 Muscles exhibited generally among the lowest concentrations for all trace elements except

134 for $\mathrm{Hg}$ which exhibited the highest values in this tissue (1.86-3.32 $\mu \mathrm{g} \mathrm{Hg} . \mathrm{g}^{-1}$ dry weight;

135 Figure 1). Cr and $\mathrm{Zn}$ were highly concentrated in the ovary with concentrations ranging from

1360.65 to $6.12 \mu \mathrm{g} \cdot \mathrm{g}^{-1}$ and 131 to $149 \mu \mathrm{g} \cdot \mathrm{g}^{-1}$, respectively. The oviduct gland also displayed high

137 concentrations of $\mathrm{As}$ and $\mathrm{Mn}$ as well as the digestive gland appendages had high 138 concentrations of $\mathrm{Cr}$ and $\mathrm{Pb}$ (Figure 1).

\subsection{Distribution of the trace elements in soft tissues}

141 The proportions of the whole body burden of the trace elements contained in each organ and

142 tissue are shown in Figure 2. With the exception of $\mathrm{As}, \mathrm{Cr}, \mathrm{Hg}$ and $\mathrm{Mn}$ which were mainly 143 found in the body muscular parts $(69 \pm 9 \%, 68 \pm 20 \%, 87 \pm 5 \%$, and $55 \pm 22 \%$, respectively),

144 the digestive gland contained the largest quantities of all trace elements : $98 \pm 1 \%$ of $\mathrm{Ag}, 99$

$145 \pm 1 \%$ of $\mathrm{Cd}, 97 \pm 2 \%$ of $\mathrm{Co}, 92 \pm 5 \%$ of $\mathrm{Cu}, 85 \pm 16 \%$ of $\mathrm{Fe}, 53 \pm 28 \%$ of $\mathrm{Ni}, 69 \pm 22 \%$ of

$146 \mathrm{~Pb}, 77 \pm 5 \%$ of Se, $71 \pm 19 \%$ of $\mathrm{V}$, and $53 \pm 17 \%$ of $\mathrm{Zn}$ (Figure 2 ).

147 Although the concentrations of some trace elements were high in the branchial hearts or in 148 the gills, these tissues contained in fact low amounts of the considered elements because of 149 their small masses relative to the whole body weight (Figure 2).

\subsection{Influence of the size/weight and origin}

152 The size/weight only influenced $\mathrm{Zn}$ concentrations in the digestive gland $\left(\mathrm{R}^{2}=0.934, \mathrm{p}=0.020\right)$

153 and $\mathrm{Cr}$ and Ni concentrations in the gills $\left(\mathrm{R}^{2}=0.968 \mathrm{p}=0.007\right.$ and $\left.\mathrm{R}^{2}=0.969 \mathrm{p}=0.007\right)$.

154 No statistical tests were performed to compare the influence of the origin on the accumulated

155 trace elements because our sampling only included one specimen from the Mediterranean. 
156 However, this giant squid clearly displayed higher concentrations of $\mathrm{Hg}$ than any of those

157 from the Bay of Biscay with 1.56 vs $0.47 \pm 0.13 \mu \mathrm{g} \cdot \mathrm{g}^{-1}$ in the digestive gland (see Table 3 ),

1582.97 vs $1.38 \pm 0.34 \mu \mathrm{g} \cdot \mathrm{g}^{-1}$ in the gills, and 3.32 vs $2.07 \pm 0.19 \mu \mathrm{g} \cdot \mathrm{g}^{-1}$ in the mantle muscle

159 (data not shown). Important differences also appeared for $\mathrm{Ag}, \mathrm{Cu}$ and $\mathrm{Zn}$ with 14.0 vs $1.90 \pm$ $160 \quad 0.47 \mu \mathrm{g} \mathrm{Ag.g}{ }^{-1}, 1218$ vs $108 \pm 83 \mu \mathrm{g} \mathrm{Cu} . \mathrm{g}^{-1}$, and 219 vs $103 \pm 51 \mu \mathrm{g} \mathrm{Zn.g}{ }^{-1}$ in the digestive

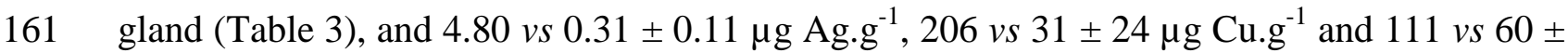
$16235 \mu \mathrm{g} \mathrm{Zn} . \mathrm{g}^{-1}$ in the gills (data not shown).

163

\section{Discussion}

Previous studies have demonstrated the ability of cephalopods to accumulate high

167 concentrations of trace elements in their tissues but very little data is available in the current

168 literature for non-targeted and/or deep-waters species such as the giant squid Architeuthis.

169 Although globally poorly documented, metal and metalloid concentrations in cephalopod

170 tissues have received increasing interest over the last decades, particularly in Europe and

171 Japan, as these molluscs play a major role both as predators and food items in marine

172 ecosystems (see the reviews by Clarke 1996; Croxall and Prince 1996; Klages 1996; Smale

173 1996; Boyle and Rodhouse, 2005). The central role of the digestive gland in trace element

174 bioaccumulation and detoxification has been highlighted many times, particularly for toxic

175 metals such as Ag and Cd (e.g. Martin and Flegal 1975; Miramand and Bentley 1992;

176 Bustamante et al., 2002, 2004; Ichiashi et al., 2001a; Miramand et al., 2006). Beside the

177 digestive gland, which also plays a major role in the energetic metabolism of cephalopods

178 (e.g. Rosa et al., 2005; Moltschaniwskyj and Johnston 2006), the branchial hearts and their

179 appendages are involved in trace element excretion processes, allowing the depuration and/or

180 the storage of various metals and radionuclides (e.g. Nardi and Steinberg 1974; Miramand 
and Guary 1980; Guary et al., 1981; Miramand and Bentley 1992; González et al., 1998;

182 Bustamante et al., 2002, 2006b). As for coastal and/or oceanic targeted cephalopods, the 183 digestive gland and the branchial hearts of Architeuthis generally contained the highest 184 concentrations of most of the considered elements, i.e. $\mathrm{Ag}, \mathrm{Cd}, \mathrm{Co}, \mathrm{Cu}, \mathrm{Fe}, \mathrm{Ni}, \mathrm{Se}, \mathrm{V}$ and $\mathrm{Zn}$

185 (Figure 1). This finding strongly suggests that the metabolism of trace elements in 186 Architeuthis is very close to, or even the same as other families of cephalopods. This is 187 supported by the fact that trace element concentrations in the digestive gland of Architeuthis 188 closely fall within the same range than for other cephalopod species (Table 3), indicating that 189 the potential of Architeuthis for their bioaccumulation is relatively similar. Moreover, 190 according to the elevated proportions of the total element body burden, the digestive gland of 191 Architeuthis might play a central role in the detoxification and storage of most of the 192 analysed elements, i.e. $\mathrm{Ag}, \mathrm{Cd}, \mathrm{Co}, \mathrm{Cu}, \mathrm{Fe}, \mathrm{Ni}, \mathrm{Pb}, \mathrm{Se}, \mathrm{V}$ and $\mathrm{Zn}$ (Figure 2). It would be a 193 great interest to investigate the detoxification strategies in the digestive gland of Architeuthis 194 in comparison to that of other families of cephalopods.

195 Besides the digestive gland, muscles contained very high proportions of total body burdens 196 of $\mathrm{As}, \mathrm{Cr}, \mathrm{Hg}, \mathrm{Mn}, \mathrm{Ni}$, and $\mathrm{Zn}$ (Figure 2). With the exception of $\mathrm{Hg}$, trace element 197 concentrations in Architeuthis muscles were relatively low and these high proportions 198 resulted from the elevated muscular mass respective to the whole body weight. For $\mathrm{Hg}$, the 199 concentrations recorded in the muscles were the highest among the different organs and 200 tissues (Figure 1). Previous studies have reported relatively similar $\mathrm{Hg}$ concentrations 201 between the different tissues of different squid species from the Northern Atlantic waters 202 (Bustamante et al., 2006a; Pierce et al., 2008). It is therefore noteworthy that muscular $\mathrm{Hg}$ concentrations in Architeuthis were 2 to 4 times higher than in the digestive gland. In 204 comparison with $\mathrm{Ag}, \mathrm{Cd}, \mathrm{Co}, \mathrm{Cu}, \mathrm{Fe}, \mathrm{Ni}, \mathrm{Pb}, \mathrm{Se}, \mathrm{V}$ and $\mathrm{Zn}$, the role of the digestive gland in 205 the storage of $\mathrm{Hg}$ appeared to be relatively limited in Architeuthis. This may be due to an 
excretion function of $\mathrm{Hg}$ by the digestive gland, and/or a preferential redistribution of $\mathrm{Hg}$ to

207 muscular tissues where it binds to the sulphydryl groups of proteins (Bloom, 1992;

208 Bustamante et al., 2006a). Such a redistribution might indicate that most of the Hg ingested

209 from the prey would be in the organic form such as fish in which $\mathrm{Hg}$ content is virtually

$210100 \%$ in the methylated form (Bloom, 1992). Little is known about the diet of Architeuthis,

211 it includes other cephalopods (Pérez-Gándaras and Guerra, 1978, 1989), crustaceans (e.g.

212 Nephros norvergicus) as well as a large proportion of fish of different families accordingly to

213 the available prey in the area (for instance Trachurus trachurus, Maurolicus muelleri and

214 Micromesistius poutassou in Ireland waters and equivalent species from Namibia and New

215 Zealand) (see Guerra et al., 2006 for a review). Further studies therefore should focus on

216 trace elements in the typical prey of Architeuthis to provide insights on this aspect.

217 As in other cephalopod species, trace element concentrations in Architeuthis may vary with

218 biological and environmental factors such as age (size/weight), sex, and geographical origin

219 (e.g. Monteiro et al., 1992; Bustamante et al., 1998; Raimundo et al., 2004; Pierce et al.,

220 2008). Our limited sampling did not allow making comparisons for all these factors.

221 However, considering the 5 specimens from the Bay of Biscay, it appears that size/weight

222 poorly influenced trace element concentrations in Architeuthis tissues. The increase of $\mathrm{Zn}$ concentrations from 34 to $160 \mu \mathrm{g} \cdot \mathrm{g}^{-1} \mathrm{dwt}$ in the digestive gland might be related to metal physiological changes related to the sexual maturation as reported for other cephalopod species like Sepia officinalis from the English Channel (Miramand et al., 2006). In females, 226 high concentrations of $\mathrm{Zn}$ in the ovary of Architeuthis $\left(120 \pm 38 \mu \mathrm{g} \cdot \mathrm{g}^{-1} \mathrm{dwt}\right)$ were close to 227 that in the genital tract of Sepia officinalis $\left(123 \pm 3 \mu \mathrm{g} \cdot \mathrm{g}^{-1} \mathrm{dwt}\right.$; Miramand and Bentley, 228 1992). Within the ovary, essential elements such as $\mathrm{Zn}$ are stored in metal-containing enzymes and metalloproteins (Gerpe et al., 2000) and transferred to the yolk of the eggs

230 (Villanueva and Bustamante, 2006, Lacoue-Labarthe et al., 2008). Cr and Ni in the gills also 
displayed a significant increase with size/weight. In the current literature, very little data is

232 available on the variation of $\mathrm{Cr}$ and $\mathrm{Ni}$ concentrations in cephalopod tissues. For example, in

233 the squid Sthenoteuthis oualaniensis $\mathrm{Cr}$ concentrations were higher in juveniles than in

234 adults, whereas juveniles displayed lower Ni concentrations than adults (Ichihashi et al., 235 2001a). Such a difference for S. oualaniensis was explained by the evolution of food habits 236 between the juvenile and adult stages, juvenile feeding more on crustaceans while adults 237 primarily preyed on fish. According to the lack of significant variation in the digestive gland, 238 such a switch is not likely to occur in the size range of Architeuthis we analysed. 239 Furthermore, even if the diet could represent the main pathway for many elements - as 240 experimentally shown for Am, Cd, Co and Zn (Koyama et al., 2000; Bustamante et al., 2002, $2412004,2006 b)$ - seawater could also be an important uptake pathway, as elements pass 242 through the skin and through the gills. For instance, seawater represents the main pathway for 243 Ag in Sepia officinalis (Bustamante et al., 2004). Therefore, $\mathrm{Cr}$ and Ni bioaccumulation in 244 gills might also result from a direct uptake from seawater all along the lifespan of 245 Architeuthis.

246 Trace element concentrations in cephalopods could also vary according the location where 247 individuals were captured (Bustamante et al., 1998; Seixas et al., 2005ab; Pierce et al., 2008). 248 In the case of Architeuthis, this is clearly exemplified by the much higher $\mathrm{Hg}$ concentrations 249 in the tissue of the specimen from the Mediterranean. Higher $\mathrm{Hg}$ concentrations in 250 Mediterranean organisms have been highlighted many times and are typically explained by 251 high temperatures and absence of solar radiation in the deep environment. These conditions 252 favor a high methylation rate of the metal, methyl-Hg being highly bioavailable for marine 253 biota, which consistently biomagnifies through the food chain. Moreover, natural sources of $254 \mathrm{Hg}$ in the Mediterranean Sea may contribute to $\mathrm{Hg}$ enrichment through the benthic food webs, 255 as it constitutes the richest natural reserve of this element (Bacci, 1989). Higher $\mathrm{Ag}, \mathrm{Cu}$ and 
$\mathrm{Zn}$ concentrations in the digestive gland and in the gills also indicated different exposure conditions of this specimen compared to those from the Bay of Biscay. In cephalopods, Ag bioaccumulation in the digestive gland might reflect the global contamination of the surrounding waters (e.g. Martin and Flegal, 1975; Miramand et al., 2006), seawater being the main pathway of exposure and Ag having a fast turn-over in the tissues (Bustamante et al., 2004). Interestingly, $\mathrm{Ag}, \mathrm{Cu}, \mathrm{Hg}$ and $\mathrm{Zn}$ are metals that bind to metallothionein proteins 262 (MTs), which play a role in the homeostasis of the essential metals (i.e. $\mathrm{Cu}$ and $\mathrm{Zn}$ ) and in the detoxification of non-essential metals (i.e. $\mathrm{Ag}, \mathrm{Cd}$ and $\mathrm{Hg}$ ) (Roesijadi, 1992, 1996;

264 Viarengo and Nott, 1993). The role of MTs in metal sequestration in cephalopods is not completely clear (Bustamante et al., 2006c) and this issue clearly deserves further 266 investigation.

267 Even though trace elements are generally considered for their potential toxicity in 268 ecotoxicological studies and biomonitoring surveys, there is increasing interest in their use for providing information on life history and trophic ecology of cephalopods (Jackson et al., 2007). Thus, Cd is of particular interest because it is highly bioaccumulated by cephalopods. 271 Indeed, Cd is efficiently absorbed and strongly retained in the digestive gland (Bustamante et 272 al., 1998, 2002). Even if most of cephalopod species display short life spans i.e. typically less than 2 years, they can accumulate very high $\mathrm{Cd}$ concentrations in their digestive gland 274 reaching up $1000 \mu \mathrm{g} \mathrm{g}^{-1}$ wet wt in the squid Illex argentinus (Dorneles et al., 2007). Because of $\mathrm{Cd}$ incorporation by organisms in epipelagic waters and its regeneration from sinking 276 biological debris in the mesopelagic environment (Boyle et al., 1976), deep-water 277 cephalopods might show relatively high $\mathrm{Cd}$ concentrations. In the Bay of Biscay, $\mathrm{Cd}$ 278 concentrations reached 9.1 and $33.1 \mu \mathrm{g} . \mathrm{g}^{-1}$ dry wt in the digestive gland of the mesopelagic squids Histioteuthis reversa and Teuthowenia megalops, respectively (unpublished data) and

280 would be due to the consumption of prey highly contaminated with $\mathrm{Cd}$. Even elevated 
compared to neritic squid species (Bustamante et al., 1998), these concentrations are lower

282 than those measured in the digestive gland of Architeuthis, suggesting that 1) the giant squid 283 feed on more contaminated prey than Histioteuthidae and Cranchidae, or 2) it displays a much longer life span that other cephalopods. Age estimation and growth rates of giant squids are still open questions. Indeed, isotopic analysis indicated that the age for the giant squid Architeuthis sanctipauli from Tasmania was 14 years for specimens ranging from 191 to $240 \mathrm{~cm}$ ML (Landman et al., 2004). This completely disagrees with the age estimated from growth increment counts in statoliths of Architeuthis dux and Architeuthis sp. from the Atlantic and caught off New Zealand. Specimens ranging from 43 to $161 \mathrm{~cm}$ ML had between 153 and 435 increments (Jackson et al., 1991; Gauldie et al., 1994; Lordan et al., 1998; González et al., 2002). If the increments were daily deposited, as it occurs in other cephalopods, the age of these animals will not exceed two years. This finding implies that Architeuthis would have a very fast growth rate with intense food intakes that in turn would lead to the bioaccumulation of relatively high $\mathrm{Cd}$ concentrations in its digestive gland.

\section{Acknowledgements}

We thank Luis Laria and other members of CEPESMA who collected the squids, Dr. Alberto Fernández Costa for his technical assistance in the dissections, and the staff of the Centre Commun d'Analyses (University of La Rochelle) for their help in the analytical process. This study was supported financially by LIENSs (University of La Rochelle).

\section{References}

Bacci, E. 1989. Mercury in the Mediterranean. Marine Pollution Bulletin 20, 59-63. 
307 Bloom, N.S. 1992. On the chemical form of mercury in edible fish and marine invertebrate 308 tissue. Canadian Journal of Fisheries and Aquatic Sciences 49, 1010-1017.

Boyle, E.A., Sclater, F., Edmond, J.M. 1976. On the marine geochemistry of cadmium. Nature $263,42-44$.

312

313 Boyle, P.R., Rodhouse, P.G. 2005. Cephalopods: Ecology and Fisheries. Blackwell Science, Oxford, 314 United Kingdom.

316 Bustamante, P., Caurant, F., Fowler, S.W., Miramand, P. 1998. Cephalopods as a vector for the transfer of cadmium to top marine predators in the north-east Atlantic Ocean. Science of the Total Environment 220, 71-80.

Bustamante, P., Grigioni, S., Boucher-Rodoni, R., Caurant, F., Miramand, P. 2000.

321 Bioaccumulation of 12 trace elements in the tissues of the nautilus Nautilus macromphalus from New Caledonia. Marine Pollution Bulletin 40, 688-696.

Bustamante, P., Teyssié, J-L., Fowler, S.W., Cotret, O., Danis, B., Miramand, P., Warnau, M. 2002. Biokinetics of zinc and cadmium accumulation and depuration at different stages in the life cycle of the cuttlefish Sepia officinalis. Marine Ecology Progress Series 231, 167-177.

Bustamante, P., Teyssié, J-L., Fowler, S.W., Danis, B., Cotret, O., Miramand, P., Warnau, M. 2004. Uptake, transfer and distribution of silver and cobalt in the tissues of the common cuttlefish Sepia officinalis at different stages of its life cycle. Marine Ecology Progress Series $269,185-195$. 
333 Bustamante, P., Lahaye, V., Durnez, C., Churlaud, C., Caurant, F. 2006a. Total and organic Hg concentrations in cephalopods from the North East Atlantic waters: influence of geographical origin and feeding ecology. Science of the Total Environment, 368: 585-596.

Bustamante, P., Teyssié, J-L., Fowler, S.W., Warnau, M. 2006b. Assessment of the exposure pathway in the uptake and distribution of americium and cesium in cuttlefish (Sepia officinalis) at different stages of its life cycle. Journal of Experimental Marine Biology and Ecology 331, 198-207.

Bustamante, P., Bertrand, M., Boucaud-Camou, E., Miramand, P. 2006c. Subcellular distribution of $\mathrm{Ag}, \mathrm{Cd}, \mathrm{Co}, \mathrm{Cu}, \mathrm{Fe}, \mathrm{Mn}, \mathrm{Pb}$ and $\mathrm{Zn}$ in the digestive gland of the common cuttlefish Sepia officinalis. Journal of Shellfish Research 3, 987-994.

Cherel, Y., Hobson, K.A. 2005. Stable isotopes, beaks and predators: a new tool to study the trophic ecology of cephalopods, including giant and colossal squids. Proceedings of the Royal 348 Society B 272, 1601-1607.

Clarke, M.R. 1996. Cephalopods as prey. III. Cetaceans. Philosophical Transactions of the Royal Society of London. Series B, Biological Sciences 351, 1053-1065.

Croxall, J.P., Prince, P.A. 1996. Cephalopods as prey. I. Seabirds. Philosophical transactions of the Royal Society of London. Series B, Biological Sciences 351, 1023-1043. 
356 Dorneles, P.R., Lailson-Brito, J., dos Santos, R.A., Silva da Costa, P.A., Malm, O., Azevedo, 357 A.F., Machado Torres, J.P. 2007. Cephalopods and cetaceans as indicators of offshore 358 bioavailability of cadmium off Central South Brazil Bight. Environmental Pollution 148, 352359359.

361 Finger, J.M., Smith, J.D. 1987. Molecular association of $\mathrm{Cu}, \mathrm{Zn}, \mathrm{Cd}$ and ${ }^{210} \mathrm{Po}$ in the digestive 362 gland of the squid Nototodarus gouldi. Marine Biology 95, 87-91.

364 Gauldie, R.W., West, I.F., Förch, E.C. 1994. Statocyst, statolith, and age estimation of the 365 giant squid, Architeuthis kirki. The Veliger 37(1), 93-109.

Gerpe, M.S., de Moreno, J.E.A., Moreno, V.J., Patat, M.L. 2000. Cadmium, zinc and copper 368 accumulation in the squid Illex argentinus from the Southwest Atlantic Ocean. Marine Biology $136,1039-1044$.

González, A.F., Guerra, A., Pascual, S. \& Briand, P. 1998. Vulcanoctopus hydrothermalis gen. 372 et sp. nov. (Mollusca, Cephalopoda): a new octopod from a deep sea hydrothermal vent. 373 Cahiers de Biologie Marine 39, 169-184.

375 González, A.F., Guerra, A., Rocha, F., Gracia, J. 2002. Recent findings of the giant squid 376 Architeuthis in northern Spanish waters. Journal of the Marine Biological Association of the 377 United Kingdom 82, 859-861. 
379 Guary, J-C., Higgo, J.J.W., Cherry, R.D., Heyraud, M. 1981. High concentrations of 380 transuranic and natural radioactive elements in the branchial hearts of the cephalopods Octopus 381 vulgaris. Marine Ecology Progress Series 4, 123-126.

Guerra, A., González, A.F., Dawe, E.G., Rocha, F. 2004. A review of records of giant squid in

384 the north-eastern Atlantic, with a note on the two first records of males Architeuthis sp. off the Iberian Peninsula. Journal of the Marine Biological Association of the United Kingdom 84, $427-431$

Guerra, A., González, A.F., Rocha, F., Laria, L., Gracia, J. 2006. Enigmas de la ciencia: el calamar gigante. Guerra, A. et al., (eds.). Instituto de Investigaciones Marinas (CSIC, Vigo), 313 pp., 88 figs.

Honda, K., Tatsukawa, R., Itano, K., Miyazaki, N., Fujiyama, T. 1983. Heavy metal concentrations in muscle, liver and kidney tissue of striped dolphin, Stenella coeruleoalba, and their variations with body length, weight, age and sex. Agric Biol Chem 47(6), 1219-1228.

Ichihashi, H., Kohno, H., Kannan, K., Tsumura, A., Yamasaki, S.I. 2001a. Multielemental analysis of purpleback flying squid using high resolution inductively coupled plasma-mass spectrometry (HR ICP-MS). Environmental Science and Technology 35, 3103-3108.

Ichihashi, H., Nakamura, Y., Kannan, K., Tsumura, A., Yamasaki, S.I. 2001b. Multi-elemental concentrations in tissues of Japanese common Squid (Todarodes pacificus). Archives of 
404 Jackson, G.D., Lu, C.C., Dunning, M.C. 1991. Growth rings within the statolith microstructure 405 of the giant squid Architeuthis. The Veliger 34 (4), 331-334.

406

407 Jackson, G.D., Bustamante, P., Cherel, Y., Fulton, A., Grist, E.P.M., Jackson, C.H., Nichols, 408 P.D., Pethybridge, H., Phillips, K., Ward, R.D., Xavier, J.C. 2007. Applying new tools to 409 cephalopod trophic dynamics and ecology: perspectives from the Southern Ocean Cephalopod 410 Workshop, February 2-3, 2006. Reviews in Fish Biology and Fisheries 17, 79-99.

Klages, N.T.W. 1996. Cephalopods as prey. II. Seals. Philosophical transactions of the Royal Society of London. Series B, Biological Sciences 351, 1045-1052.

Koyama, J., Nanamori, N., Segawa, S. 2000. Bioaccumulation of waterborne and dietary 416 cadmium by oval squid Sepioteuthis lessoniana, and its distribution among organs. Marine Pollution Bulletin 40, 961-967.

Kubodera, T., Mori, K. 2005. First-ever observations of a live giant squid in the wild. Proceedings of the Royal Society B 272, 2583-2586. 2008. First experiments on the maternal transfer of heavy metals in the cuttlefish, Sepia officinalis. Marine Pollution Bulletin 57, 826-831.

Lahaye, V., Bustamante, P., Spitz, J., Das, K., Meynier, L., Magnin, V., Dabin, W., Caurant, F. 2005. Long-term dietary preferences of common dolphins in the Bay of Biscay using a metallic tracer. Marine Ecology Progress Series 305, 275-285. 
430 Landman, N.H., Cochran, J.K, Cerrato, R., Mak, J., Roper, C.F.E., Lu, C.C. 2004. Habitat and 431 age of the giant squid (Architeuthis sanctipauli) inferred from isotopic analyses. Marine 432 Biology 144, 685-691.

Lordan, C., Collins, M.A., Raya, C.P. 1998. Observations on morphology, age and diet of three

Architeuthis caught off the west coast of Ireland in 1995. Journal of the Marine Biological Association of the United Kingdom 78, 903-917.

Martin, J.H., Flegal, A.R. 1975. High copper concentrations in squid livers in association with elevated levels of silver, cadmium, and zinc. Marine Biology 30, 51-55.

440

441 Miramand, P., Guary, J-C. 1980. High concentrations of some heavy metals in tissues of the Mediterranean octopus. Bulletin of Environmental Contamination and Toxicology 24, 783-788.

Miramand, P., Bentley, D. 1992. Concentration and distribution of heavy metals in tissues of two cephalopods, Eledone cirrhosa and Sepia officinalis, from the French coast of the English Channel. Marine Biology 114, 407-414.

Miramand, P., Bustamante, P., Bentley, D., Koueta, N. 2006. Variation of heavy metal concentrations ( $\mathrm{Ag}, \mathrm{Cd}, \mathrm{Co}, \mathrm{Cu}, \mathrm{Fe}, \mathrm{Pb}, \mathrm{V}, \mathrm{Zn}$ ) during the life cycle of the common cuttlefish Sepia officinalis. Science of the Total Environment 361, 132-143. 
452 Moltschaniwskyj, N., Johnston, D. 2006. Evidence that lipid can be digested by the dumpling 453 squid Euprymna tasmanica, but is not stored in the digestive gland. Marine Biology 149, 565454572.

455

456 Monteiro, L.R., Porteiro, F.M., Gonçalves, J.M. 1992. Inter- and intra-specific variation of 457 mercury levels in muscle of cephalopods from the Azores. Arquipelago 10, 13-22.

458

459 Monteiro, L.R., Costa, V., Furness, R.W., Santos, R.S. 1996. Mercury concentrations in prey 460 fish indicate enhanced bioaccumulation in mesopelagic environments. Marine Ecology 461 Progress Series 141, 21-25.

462

463 Muirhead, S.J., Furness, R.W. 1988. Heavy metal concentrations in the tissues of seabirds from 464 Gough Island, South Atlantic Ocean. Marine Pollution Bulletin 19, 278-283.

465

466 Nardi, G., Steinberg, H. 1974. Isolation and distribution of adenochrome(s) in Octopus 467 vulgaris. Comparative Biochemistry and Physiology 48 B, 453-461.

468

469 Pérez-Gándaras, G., Guerra, A. 1978. Nueva cita de Architeuthis (Cephalopoda: Teuthoidea):

470 descripción y alimentación. Investigación Pesquera 42 (2), 401-414.

471

472 Pérez-Gándaras, G., Guerra, A. 1989. Architeuthis de Sudafrica: nuevas citas y consideraciones 473 biológicas. Scientia Marina 53, 113-116.

474 
475 Pierce, G.J., Stowasser, G., Hastie, L.C., Bustamante, P. 2008. Geographic, seasonal and 476 ontogenetic variation in cadmium and mercury concentrations in squid (Cephalopoda: 477 Teuthoidea) from UK waters. Ecotoxicology and Environmental Safety 70, 422-432

478

479 Raimundo, J., Caetano, M., Vale, C. 2004. Geographical variation and partition of metals in 480 tissues of Octopus vulgaris along the Portuguese coast. Science of the Total Environment 325, $481 \quad 71-81$.

482

Roesijadi, G. 1992. Metallothionein in metal regulation and toxicity in aquatic animals. Aquatic Toxicology 22, 81-114.

Roesijadi, G. 1996. Metallothionein and its role in toxic metal regulation. Comparative Biochemistry and Physiology 113C, 117-123.

Roper, C.F.E., Boss, K.J. 1982. The giant squid. Scientific American 246, 96-105.

490

491 Rosa, R., Pereira, J.M.F., Nunes, M.L. 2005. Biochemical composition of cephalopods with 492 different life strategies, with special reference to a giant squid, Architeuthis sp. Marine Biology 493 $146,739-751$.

494

495 Santos, M.B., Pierce, G.J., García Hartmann, M., Smeenk, C., Addink, M.J., Kuiken, T., Reid, 496 R.J., Patterson, I.A.P., Lordan, C., Rogan, E., Mente, E. 2002. Additional notes on stomach 497 contents of sperm whales Physeter macrocephalus stranded in the north-east Atlantic. Journal 498 of the Marine Biological Association of the United Kingdom 82(3), 501-507. 
500 Seixas, S., Pierce, G.J. 2005a. Vanadium, rubidium and potassium in Octopus vulgaris

501 (Mollusca: Cephalopoda). Scientia Marina 69(2), 215-222.

502

503 Seixas, S., Pierce, G.J. 2005b. Bioaccumulation of lead, calcium and strontium and their 504 relationships in the octopus Octopus vulgaris. Water, Air, and Soil Pollution 163, 137-152.

505

506 Seixas, S., Bustamante, P., Pierce, G.J. 2005a. Accumulation of mercury in the tissues of the 507 common octopus Octopus vulgaris (L.) in two localities on the Portuguese coast. Science of the Total Environment 340, 113-122.

509

510 Seixas, S., Bustamante, P., Pierce, G.J. 2005b. Interannual patterns of variation in 511 concentrations of trace elements in arms of Octopus vulgaris. Chemosphere 59, 1113-1124.

513 Smale, M.J. 1996. Cephalopods as prey. IV. Fishes. Philosophical transactions of the Royal 514 Society of London Series B, Biological Sciences 351, 1067-1081.

516 Smith, J.D., Plues, L., Heyraud, M., Cherry, R.D. 1984. Concentrations of the elements Ag, Al, $517 \mathrm{Ca}, \mathrm{Cd}, \mathrm{Cu}, \mathrm{Fe}, \mathrm{Mg}, \mathrm{Pb}$ and $\mathrm{Zn}$, and the radionuclides ${ }^{210} \mathrm{~Pb}$ and ${ }^{210} \mathrm{Po}$ in the digestive gland of 518 the squid Nototodarus gouldi. Marine Environmental Research 13, 55-68.

520 Storelli, M.M., Barone, G., D’Addabbo R., Marcotrigano, G.O. 2006. Concentrations and 521 composition of organochlorine contaminants in different species of cephalopod molluscs from 522 the Italian waters (Adriatic Sea). Chemosphere 64, 129-134. 
524 Tanabe, S., Tanaka, H., Tatsukawa, R. 1984. Polychlorobiphenyls, DDT, and 525 hexachlorocyclohexane isomers in the western North Pacific ecosystem. Archives of 526 Environmental Contamination and Toxicology 13, 731-738.

528 Ueda, T., Nakahara, M., Ishii, T., Suzuki, Y., Suzuki, H. 1979. Amounts of trace elements in 529 marine cephalopods. Journal of Radioactivity Research 20, 338-342.

531 Ueno, D., Inoue, S., Ikeda, K., Tanaka, H., Yamada, H., Tanabe, S. 2003. Specific 532 accumulation of polychlorinated biphenyls and organochlorine pesticides in Japanese common 533 squid as a bioindicator. Environmental Pollution 125, 227-235.

535 Viarengo, A., Nott, J.A. 1993. Mini-review. Mechanisms of heavy metal cation homeostasis in 536 marine invertebrates. Comparitive Biochemisty and Physiology 104C, 355-372.

538 Villanueva, R., Bustamante, P. 2006. Composition in essential and non-essential elements of 539 early stages of cephalopods and dietary effects on the elemental profiles of Octopus vulgaris 540 paralarvae. Aquaculture 261, 225-240.

542 Yamada, H., Takayanagi, K., Tateishi. M., Tagata, H., Ikeda, K. 1997. Organotin compounds 543 and polychlorinated biphenyls of livers in squid collected from coastal waters and Open Ocean. 544 Environmental Pollution 96(2), 217-226. 
Table 1. Sampling information and squid biological characteristics. T: trawling; S: Stranded; F: Floating at the surface; ML: Dorsal mantle length; TL: Total length.

\begin{tabular}{|c|c|c|c|c|c|c|c|}
\hline $\mathrm{N}^{\circ}$ & Sampling site & Sampling date & Mode of capture & $\begin{array}{c}\text { Weight } \\
(\mathrm{kg})\end{array}$ & $\begin{array}{l}\text { ML } \\
(\mathrm{cm})\end{array}$ & $\begin{array}{l}\mathrm{TL} \\
(\mathrm{cm})\end{array}$ & Sex / Maturation \\
\hline 1 & Off Luarca (Asturias, North Spain) & 12 September 2001 & $\mathrm{~T}$ & 90 & 127 & 710 & F/ Immature \\
\hline 2 & Ribadesella (Asturias, North Spain) & 23 October 2001 & $\mathrm{~S}$ & 104 & 150 & 800 & F/ Maturing \\
\hline 3 & Colunga (Asturias, North Spain) & 15 September 2003 & S & 80 & 152 & 1200 & F/ Immature \\
\hline 4 & Off Gijón (Asturias, North Spain) & 16 September 2003 & $\mathrm{~F}$ & 66 & 122 & 620 & M / Mature \\
\hline 5 & Off Gandía (Valencia, Western Mediterranean) & 19 July 2005 & $\mathrm{~T}$ & 50 & 107 & 600 & M / Mature \\
\hline 6 & Off Gijón (Asturias, North Spain) & 22 July 2005 & $\mathrm{~T}$ & 139 & 146 & 820 & F/ Maturing \\
\hline
\end{tabular}


Table 2. Comparison of certified trace elements concentrations $\left(\mu \mathrm{g} \mathrm{g}^{-1}\right.$ dry weight) in reference materials $(\mathrm{n}=10)$ with the values determined in the present study (nc: not certified value, nd: not determined). ICP-MS - Inductively Coupled Plasma Mass Spectrometry; ICP-OES - Inductively Coupled Plasma Optical Emission Spectrometry; AMA - Advanced Mercury Analyser.

\begin{tabular}{|c|c|c|c|c|c|c|c|c|c|c|}
\hline \multirow{3}{*}{ Element } & \multirow{3}{*}{ Method } & \multicolumn{5}{|c|}{ TORT-2 } & \multicolumn{4}{|c|}{ DOLT-3 } \\
\hline & & \multicolumn{2}{|c|}{ Measured } & \multicolumn{2}{|c|}{ Certified } & \multirow{2}{*}{ Recovery } & Measured & \multicolumn{2}{|c|}{ Certified } & \multirow{2}{*}{ Recovery } \\
\hline & & Mean & $\pm \mathrm{SD}$ & Mean & $\pm \mathrm{SD}$ & & Mean \pm SD & Mean & $\pm \mathrm{SD}$ & \\
\hline $\mathrm{Ag}$ & ICP-MS & 6.21 & \pm 1.69 & & $\mathrm{nc}$ & - & $1.21 \pm 0.10$ & 1.20 & \pm 0.07 & 101 \\
\hline As & ICP-OES & 21.8 & $\pm \quad 2.4$ & 21.6 & \pm 1.8 & 101 & $9.9 \pm 0.3$ & 10.2 & \pm 0.5 & 97 \\
\hline $\mathrm{Cd}$ & ICP-MS & 26.4 & $\pm \quad 2.2$ & 26.7 & \pm 0.6 & 99 & $19.3 \pm 0.7$ & 19.4 & \pm 0.6 & 99 \\
\hline $\mathrm{Co}$ & ICP-MS & 0.45 & \pm 0.09 & 0.51 & \pm 0.09 & 88 & $0.29 \pm 0.05$ & & nc & - \\
\hline $\mathrm{Cr}$ & ICP-OES & 0.69 & \pm 0.18 & 0.77 & \pm 0.15 & 90 & $4.02 \pm 0.93$ & & $\mathrm{nc}$ & - \\
\hline $\mathrm{Cu}$ & ICP-OES & 95 & \pm 15 & 106 & \pm 10 & 90 & $31.9 \pm 0.7$ & 31.2 & \pm 1.0 & 99 \\
\hline $\mathrm{Fe}$ & ICP-OES & 100 & \pm 10 & 105 & \pm 13 & 95 & $1349 \pm 76$ & 1484 & \pm 57 & 91 \\
\hline $\mathrm{Hg}$ & AMA & 0.27 & $\pm \quad 0.01$ & 0.27 & \pm 0.06 & 100 & $3.36 \pm 0.08$ & 3.37 & \pm 0.14 & 100 \\
\hline $\mathrm{Mn}$ & ICP-OES & 13.5 & \pm 2.0 & 13.6 & \pm 1.2 & 99 & $9.73 \pm 0.14$ & & $\mathrm{nc}$ & - \\
\hline $\mathrm{Ni}$ & ICP-OES & 2.44 & \pm 0.56 & 2.50 & \pm 0.19 & 98 & $2.46 \pm 0.45$ & 2.72 & \pm 0.35 & 90 \\
\hline $\mathrm{Pb}$ & ICP-MS & 0.32 & \pm 0.17 & 0.35 & \pm 0.13 & 91 & $0.294 \pm 0.056$ & 0.319 & \pm 0.045 & 92 \\
\hline $\mathrm{Se}$ & ICP-MS & 6.48 & \pm 0.48 & 5.63 & \pm 0.67 & 115 & $7.56 \pm 0.65$ & 7.06 & \pm 0.48 & 107 \\
\hline $\mathrm{V}$ & ICP-MS & 1.55 & \pm 0.24 & 1.64 & \pm 0.19 & 95 & nd & & $\mathrm{nc}$ & - \\
\hline $\mathrm{Zn}$ & ICP-OES & 188 & \pm 20 & 180 & \pm 6 & 104 & $97.3 \pm 1.4$ & 86.6 & \pm 2.4 & 116 \\
\hline
\end{tabular}


Table 3. Reported metal concentrations (Mean $\pm \mathrm{SD}, \mu \mathrm{g} \mathrm{g}{ }^{-1}$ dry weight) in the digestive gland of different cephalopod species.

\begin{tabular}{|c|c|c|c|c|c|c|c|c|c|c|c|c|c|c|}
\hline Species & $\mathrm{Ag}$ & As & $\mathrm{Cd}$ & Co & $\mathrm{Cr}$ & $\mathrm{Cu}$ & $\mathrm{Fe}$ & $\mathrm{Hg}$ & $\mathrm{Mn}$ & $\mathrm{Ni}$ & $\mathrm{Pb}$ & V & $\mathrm{Zn}$ & Reference \\
\hline \multicolumn{15}{|l|}{ Architeuthidae } \\
\hline Architeuthis dux & $1.90 \pm 0.47$ & $48 \pm 14$ & $60.8 \pm 46.2$ & $3.27 \pm 1.76$ & $0.93 \pm 0.41$ & $108 \pm 83$ & $497 \pm 779$ & $0.47 \pm 0.13$ & $2.72 \pm 2.12$ & $0.62 \pm 0.54$ & $0.41 \pm 0.33$ & $2.24 \pm 1.91$ & $103 \pm 51$ & $\mathrm{a}$ \\
\hline A. $d u x$ & 14 & 44 & 90.7 & 4.8 & 0.49 & 1218 & 158 & 1.56 & 2.26 & 1.37 & 0.85 & 1.72 & 219 & $\mathrm{~b}$ \\
\hline Nautilus macromphalus & $4.43 \pm 1.95$ & $185 \pm 64$ & $45 \pm 13$ & $5.9 \pm 3.6$ & $4.2 \pm 0.8$ & $106 \pm 46$ & $554 \pm 238$ & - & $8.9 \pm 2.0$ & $11.9 \pm 7.8$ & - & $8.0 \pm 2.3$ & $672 \pm 208$ & $\mathrm{c}$ \\
\hline \multicolumn{15}{|l|}{ Sepiidae } \\
\hline Sepia officinalis & $6.15 \pm 1.75$ & - & $12.7 \pm 0.4$ & $3.3 \pm 0.6$ & $1.1 \pm 0.1$ & $315 \pm 3$ & $244 \pm 28$ & - & $3.3 \pm 0.1$ & $1.3 \pm 0.4$ & $1.14 \pm 0.06$ & $5.0 \pm 1.3$ & $571 \pm 47$ & $\mathrm{~d}$ \\
\hline S. officinalis & $13 \pm 2$ & - & $25 \pm 5$ & $10 \pm 2$ & - & $600 \pm 10$ & $390 \pm 10$ & - & - & - & $2.2 \pm 0.5$ & $3.3 \pm 0.1$ & $1400 \pm 500$ & $\mathrm{e}$ \\
\hline Loligo opalescens & $25.1 \pm 12.6$ & - & $85.0 \pm 51.6$ & - & - & $5350 \pm 3210$ & $111 \pm 73$ & - & - & - & - & - & $247 \pm 131$ & $\mathrm{f}$ \\
\hline L. opalescens & $45.9 \pm 19.0$ & - & $122 \pm 58$ & - & - & $8370 \pm 3130$ & $87 \pm 49$ & - & - & - & - & - & $449 \pm 201$ & $\mathrm{f}$ \\
\hline \multicolumn{15}{|l|}{ Ommastrephidae } \\
\hline Nototodarus gouldi & - & - & $33 \pm 30$ & - & - & $363 \pm 238$ & - & - & - & - & - & - & $830 \pm 355$ & $\mathrm{~g}$ \\
\hline N. gouldi & $3.3 \pm 1.4$ & - & $50 \pm 25$ & - & - & $246 \pm 298$ & $745 \pm 440$ & - & $4.2 \pm 1.1$ & - & - & - & $696 \pm 295$ & $\mathrm{~h}$ \\
\hline Ommastrephes bartrami & $12.1 \pm 8.6$ & - & $287 \pm 202$ & - & - & $195 \pm 212$ & $399 \pm 204$ & - & - & - & - & - & $163 \pm 55$ & $\mathrm{f}$ \\
\hline Stenoteuthis oualaniensis & $24.1 \pm 10.9$ & - & $782 \pm 255$ & - & - & $1720 \pm 151$ & $319 \pm 67$ & - & - & - & - & - & $513 \pm 288$ & $\mathrm{f}$ \\
\hline S. oualaniensis* & 14.0 & 22.4 & 199 & 3.28 & 0.163 & 558 & 293 & 0.125 & 1.36 & 1.91 & 1.10 & 1.85 & 128 & $\mathrm{i}$ \\
\hline Todarodes pacificus* & 3.5 & 7.5 & 60 & 0.78 & 0.375 & 27.5 & 325 & 0.133 & 3.5 & 7.0 & 0.60 & 13.8 & 195 & $\mathrm{j}$ \\
\hline Eledone cirrhosa & $3.20 \pm 1.74$ & - & $24.0 \pm 1.8$ & $2.06 \pm 0.08$ & $0.8 \pm 0.1$ & $456 \pm 11$ & $287 \pm 13$ & - & $4.2 \pm 1.6$ & $2.5 \pm 0.1$ & $1.17 \pm 0.09$ & $3.3 \pm 0.5$ & $646 \pm 86$ & $\mathrm{~d}$ \\
\hline Octopus vulgaris & - & - & - & 8.8 & - & 275 & 275 & - & 2.7 & - & - & - & 1300 & $\mathrm{k}$ \\
\hline O. vulgaris & - & - & $50 \pm 10$ & - & - & $2500 \pm 700$ & $700 \pm 130$ & - & $7.0 \pm 0.5$ & - & - & $4.5 \pm 1.0$ & $1450 \pm 400$ & 1 \\
\hline O. vulgaris & & & & & & & & $0.58 \pm 0.08$ & & & $4.9 \pm 1.9$ & $7.2 \pm 6.9$ & & $\mathrm{~m}$ \\
\hline
\end{tabular}

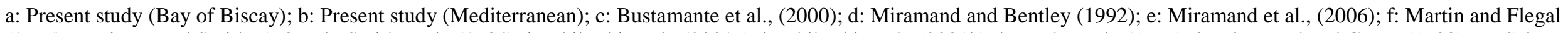

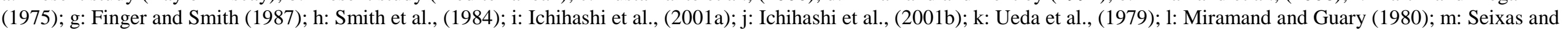
Pierce (2005ab) and Seixas et al., (2005a)

* converted to dwt using a factor of 2.5

in italics: median 


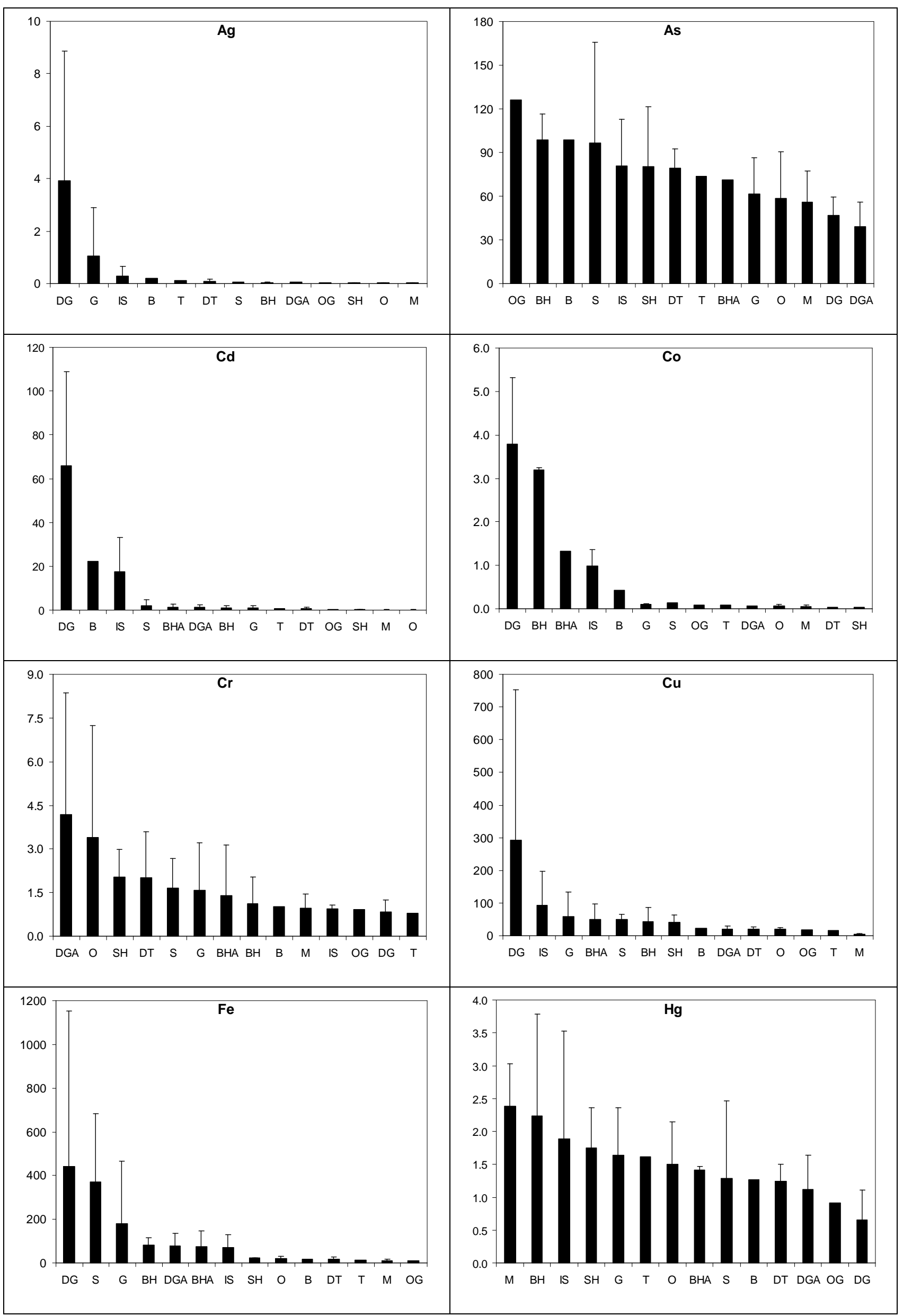




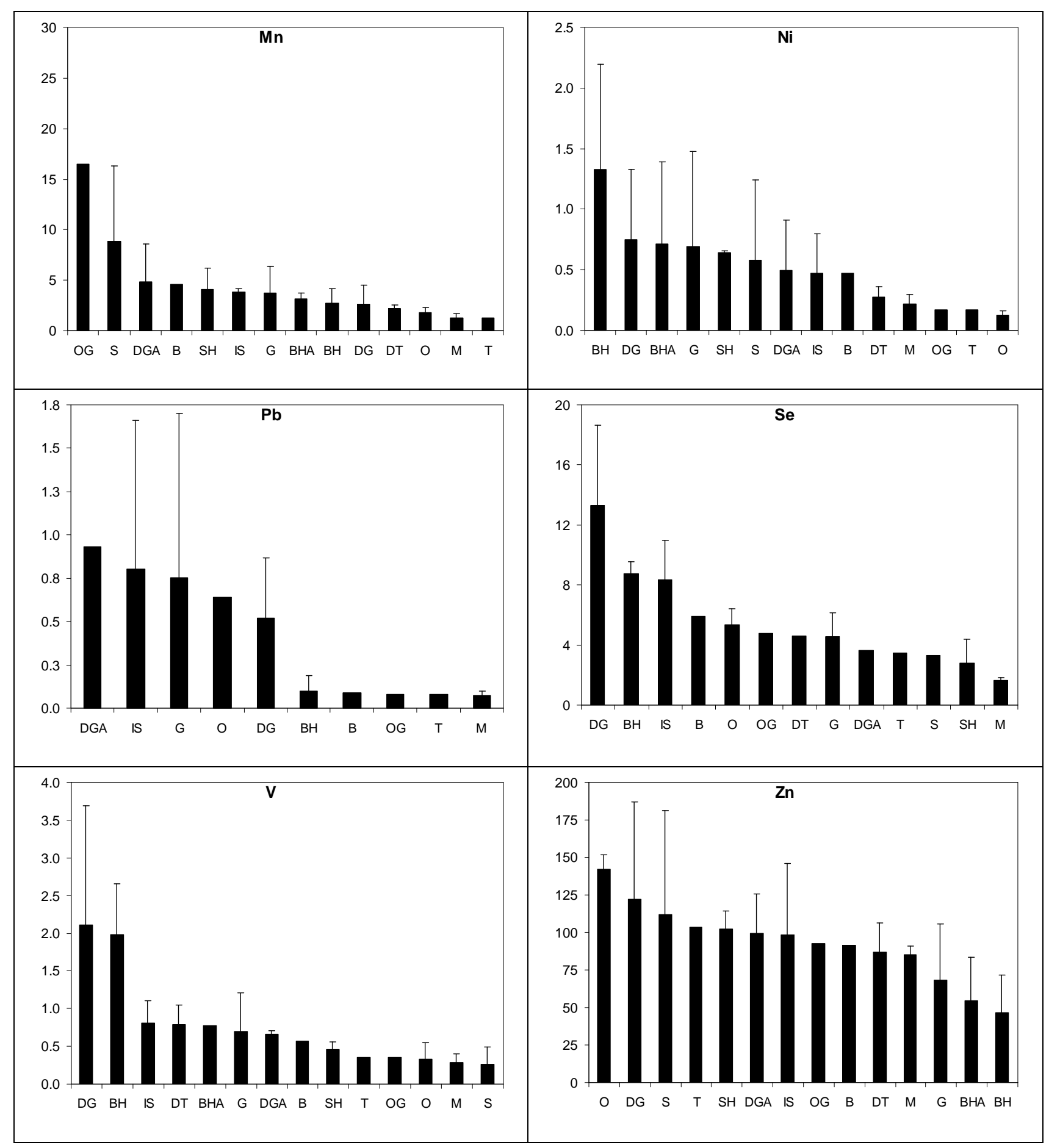

Figure 1. 


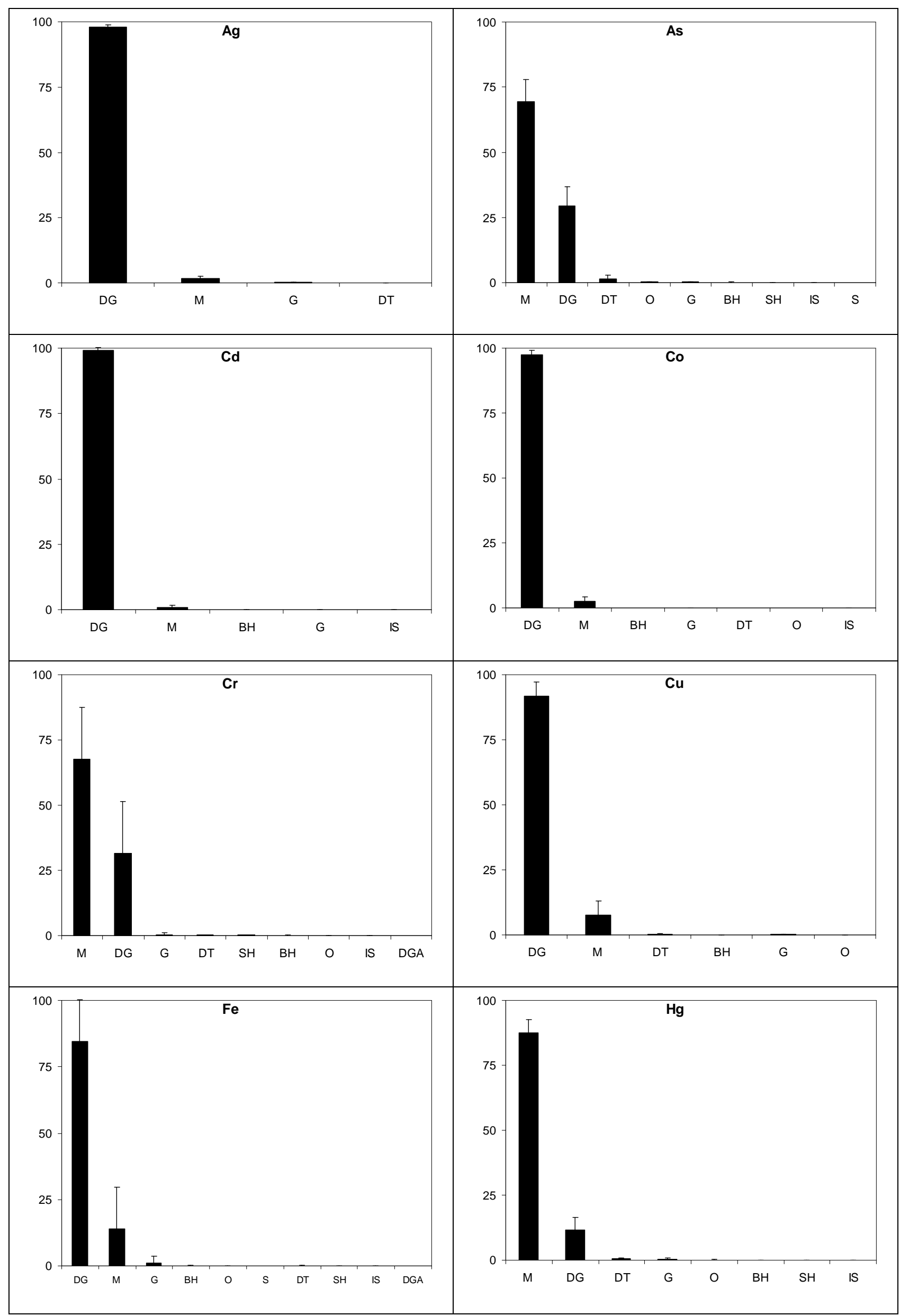




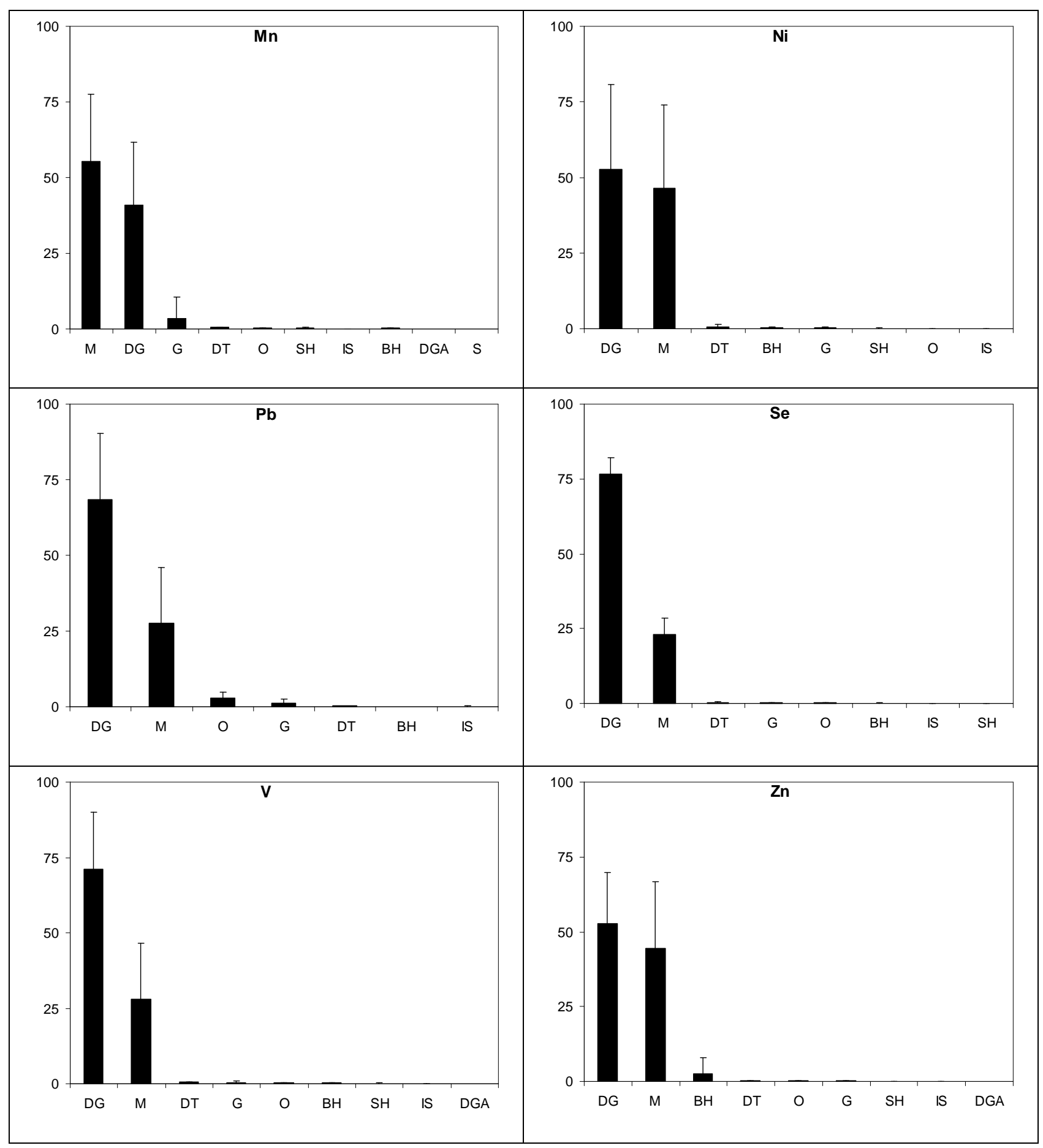

Figure 2. 